\title{
A Study on Construction of Innovation and Entrepreneurship Education Curriculum System of Tourism Management in Universities
}

\author{
Yue Wang \\ College of Business Administration, Jilin Engineering Normal University, Changchun, China \\ 51386781@qq.com
}

\begin{abstract}
Keywords: Colleges and Universities; Tourism management; Entrepreneurship education; Curriculum system
\end{abstract}

\begin{abstract}
The current international economic developing speed is becoming slow, which affects China's domestic economic development indirectly. In recent years, the economy is in the new normal circumstances. Although China's economy is mainly in a upward trend, but the development of the domestic economy growth slows, China needs to find a starting point of national economic development. Innovation and entrepreneurship education has become an important work for China's education, innovation and entrepreneurship education can motivate students to start their own businesses, increasing employment opportunities for the society, promote the rapid development of China's economy. But at present, there are still some problems in the teaching of innovation and entrepreneurship in the system of university education in our country. Therefore, it is necessary to construct the curriculum system, stimulate the students' entrepreneurial thinking and cultivate their entrepreneurial ability. Based on the analysis, this paper puts forward the innovation and entrepreneurship education curriculum system.
\end{abstract}

\section{Introduction}

Under the new economic environment and the education policy, the tourism management specialty must train the innovation talented person. Transforming the innovation education idea into the education practice needs to rely on the effective curriculum carrier [1]. Entrepreneurship education courses should be incorporated into the normal school teaching plan. The orientation, lesson period, main contents, teaching methods of the course should be clear, to ensure the effectiveness of innovation and entrepreneurship education on College students. The first task is to set up the curriculum system of tourism management major, the curriculum should be based on the idea of professional education and entrepreneurship education [2]. It is suggested that the entrepreneurship education curriculum system of tourism management major should be constructed from four modules, such as entrepreneurial spirit, entrepreneurial knowledge, entrepreneurial ability, and entrepreneurial practice, so as to achieve the goal of innovation and entrepreneurship education [3].

\section{The Ideas and Contents of Tourism Management Innovation and Entrepreneurship Education Curriculum System}

The curriculum system of entrepreneurship education in tourism management specialty is constructed under the equal emphasis of professional education and entrepreneurship education. The whole entrepreneurship education curriculum system is composed of four major modules: entrepreneurship, entrepreneurship, entrepreneurship and entrepreneurship. Each module is composed of several sub modules [4]. The construction of curriculum system mainly includes as Fig. 1. 


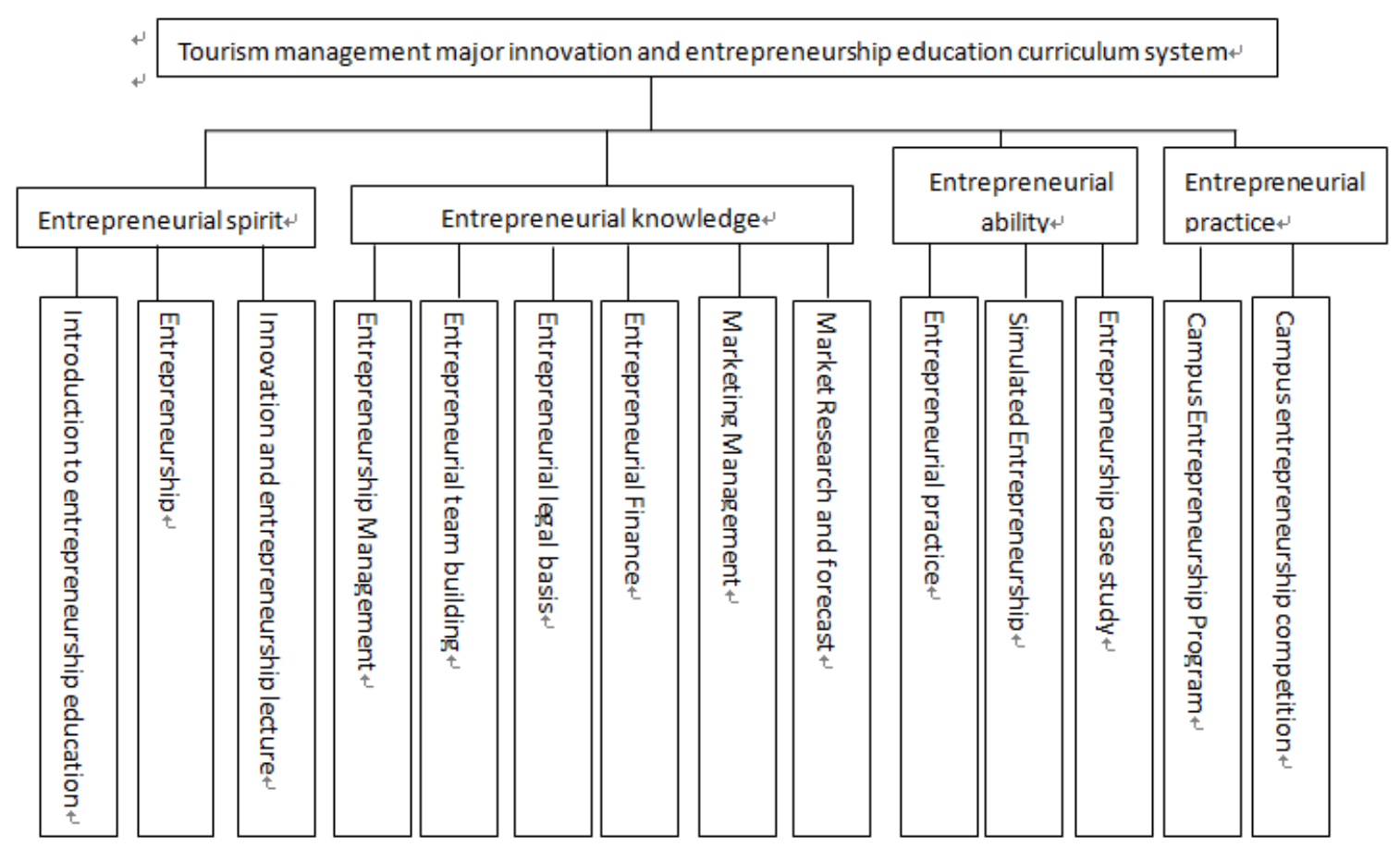

Figure 1. Tourism management major innovation and entrepreneurship education curriculum system

Entrepreneurial Spirit Module. The entrepreneurial spirit is the core of students' motivation of innovation and entrepreneurship, only through appropriate courses for students to understand "what is entrepreneurship" "why should start" the two key issues, can let the students have a sense of mission and urgency, to let the students have the learning motivation and the desire for knowledge [5].

The introduction of entrepreneurship education and Entrepreneurship these two courses are from the theoretical point of view, let students understand "what is entrepreneurship", let students understand the Chinese college students' employment forms, characteristics, difficulties and other knowledge, let students understand that they are not what the proud but living in the ivory tower of the college students. They will face a grim employment competition. China's higher education has changed from elite education to the original one of universal education now, which cultivating talents of our country. But with the graduates increased year by year, college students' employment pressure is also increasing, but the current students have not recognized this cruel reality. Muddle along in learning, for entrepreneurs is that with their distant, must let the student understand they must face the reality of the future, which is the only way to let the students get out of their fiction, stimulate their entrepreneurial motivation, cultivate students' innovative spirit and entrepreneurial consciousness.

Innovation and entrepreneurship seminars will employ social entrepreneurship independently speak for students. Though innovation and entrepreneurship in theory has certain difficulty, but it is easy for students to breed careless emotions. The process of entrepreneurship is difficult, in the course of business entrepreneurs will face numerous difficulties, not only to recognize business difficulties, students can actively enrich themselves while studying at school, after efforts to master the knowledge and entrepreneurial ability, although parents and teachers will also introduce students to a difficult start, but after all, these people are not really started. It is difficult for students to be persuasive, is only entrepreneurial young entrepreneurs, they experienced the whole process of entrepreneurship, let the students have the qualifications and ability to convince. Although the lecture may make the students understand that entrepreneurship will face difficulties, will inevitably cause students to entrepreneurship prohibitive, that he was not able to entrepreneurship, but successful entrepreneurs' returns and power can stimulate students' entrepreneurship. Opportunities and challenges coexist, the greater the risk is, the returns tend to be higher.

Entrepreneurial Knowledge Module. In addition to the determination of entrepreneurship, there must have the relevant knowledge as an auxiliary. The basic knowledge involved in the process of 
entrepreneurship including the legal basis for entrepreneurship and entrepreneurial finance [6]. China is a society ruled by law, the entrepreneurial process must have some knowledge of the law, so that can cope with the stuff at the beginning of the business enterprise establishment, as well as encountered in the process of legal disputes. Therefore, especially the creation of entrepreneurial legal basis, to teach students the contract law, civil law, commercial law, economic law, regulations and administrative measures for the registration of self-employed individuals.

Business management: management is based on the survival and development of enterprises, while students start at the beginning of may only be a person, but with the development of the entrepreneurial process, the enterprise will develop, so management become entrepreneurs' essential knowledge, good management can stimulate the work enthusiasm and improve the efficiency of enterprises and employees increase the operating costs of enterprises, so the business management professor mainly focused on enterprise organization model, to stimulate the enthusiasm of the staff, the concept of enterprise management, enterprise culture and other aspects of knowledge, from reality to application as the core.

Marketing: marketing is to study how to sell the products, and obtain the corresponding customer satisfaction and profit subject, regardless of the direction of entrepreneurship, inevitably involve marketing aspects, through marketing content, in order to make students understand and grasp the core of enterprise marketing, especially the core small business marketing, and according to the characteristics of the market and consumers, choose the suitable marketing channel and marketing.

Market Research and forecasting, is a basic discipline of marketing, marketing success, the key lies in the accuracy of market research and forecast, students must first choose the right market as a breakthrough, in addition to the student's own ability and interests, the market situation is the key to the success of entrepreneurial decision, through the course of the teaching methods to enable students to master the methods of market research and market forecast.

Entrepreneurial Capability Module. Professional education is the foundation of university education, entrepreneurship education and professional education based on the combination, in order to have a strong vitality. Although entrepreneurship does not necessarily have to learn the same professional, but from the point of view of the professional entrepreneurship, students can have a certain advantage, so the training of students' professional ability is also very important. This module focuses on the cultivation of students' entrepreneurial ability, and emphasizes the practical operation, which includes three courses: entrepreneurship practice, simulation entrepreneurship and entrepreneurship case study. Through targeted and operable business design, business operation and case teaching, business simulation and training in various forms, to make the educated with entrepreneurial steps, mastering entrepreneurial skills, cultivate students' ability to analyze and solve problems.

Business practice on the cultivation of students' practical ability, tourism is one of the professional knowledge and ability requirements are very high in the industry [7]. Educators who work for tourism major in entrepreneurship must understand and grasp the tourism industry three major industries (travel agencies, hotels, scenic spots) the main skills to the travel agency as an example, want to the travel agency industry business must understand and master the travel agency's three business skills, namely guide, planning and marketing. So set the following courses:

The tour guide service skills, this course is to teach the students the tour service process is very important in the reception skills, work process guide describes how to meet the group, in the entire tour in the original, this course is mainly from classroom teaching based on students' learning, after the tour reception of the contents have a very vague, lack of a systematic understanding [8]. therefore, can be divided into two parts of teaching courses, some hours for the remaining hours of theoretical teaching, lead the students to participate in the simulation of practical activities, from school students to the train station, airport, scenic area and other places of practice, so that students can make the book knowledge into their own knowledge, enhance memory to ensure the quality of teaching.

Tour guide practice, this course is to introduce students to the guide, at present Jilin province guide ability, which is an important direction for future development of the tourism industry in Jilin Province, but also the research of Tourism Management Majors lack of ability, can make teachers and students to practice the scenic spots of the teaching, the students are responsible for scenic spot explanation process, 
requiring every student actual operation time, teachers' explanation of each student guidance, secondly, choose Changchun city practice course has the characteristics of relatively well-known scenic spots as the practice place, this can let the students master the basic methods to explain Changchun various scenic spots, basically have the ability of handling group reception; finally, through cooperation with travel agencies, with the group form, let the students follow the tour guides have rich experience Learn the whole process of the reception of the tour group to explain the formation of knowledge in the classroom and practice lessons, deepen the memory.

Transfer of management, this course mainly introduces the method and design of tourism route of tourism products to the students of the combination and in the process of tourism for accommodation, travel shopping and entertainment content coordinated curriculum, is one of the three big travel agency business, in order to improve the teaching effect, will be arranged for students the travel agency tour by visiting students intuitive understanding of travel agency working environment and process; at the same time, will also simulate the transfer of work in the room, asked each student to simulate a number of travel arrangements for operation.

Business case study, will invite experts and entrepreneurial success and failure for the students, this course is to enable students to understand the entrepreneurial success in where, what is the reason for the failure, before the students at the start, although prepared in knowledge, but their social experience and the lack of social experience will become a student entrepreneurship the fatal case must be analysis of entrepreneurial students before the start, so as to allow students to learn how to think, to understand the social[9].

Entrepreneurial Practice Module. After training the students of entrepreneurship, entrepreneurial knowledge and entrepreneurial ability, has basically have the conditions of entrepreneurship, but the business risks, in order to ensure that every student has the ability of independent entrepreneurship, it is necessary for students in the school during the creation of the practice platform, specifically from two aspects to help students entrepreneurship practice: campus tourism business plan competition, the competition held by the school, all the requirements of tourism management students in accordance with their respective expertise and interest free entrepreneurial planning group, in groups to participate in the competition, business planning by part-time or full-time teachers and experienced in the planning process, to help students find shortage of business plan, so as to improve students' entrepreneurial ability, business plan writing after the requirements of Entrepreneurial Small Group representatives about their business plans to the judges, and in the defense process, points out the existing problems in the business plan and method of correction from a professional point of view, according to the guidance of teachers opinions and the views, select several business plans to group capital and site support, use of the tourism professional training room can be carried out the professional entrepreneurial projects to help students achieve their business plans.

\section{The Implementation of Innovation and Entrepreneurship Education Curriculum System in Tourism Management}

In the construction of entrepreneurship education curriculum system of tourism management process, according to the different abilities of students in different grades have, pay attention to the cultivation of students' ability and personality formation, expertise and focus on the development of students in different grades, different design students through university career relatively complete system of entrepreneurship education curriculum [10]. According to different grades of students and their interests, the design of the entrepreneurial spirit, entrepreneurial knowledge and entrepreneurial capabilities and entrepreneurial practice progressive entrepreneurship education process, to achieve the combination of the cultivation of students' basic quality, innovative spirit and practice ability of tourism management talents. Entrepreneurship education curriculum schedule is shown in Table 1. 
Table 1 Schedule of entrepreneurship education curriculum system of Tourism Management

\begin{tabular}{|l|l|l|l|}
\hline Arrangement & Object & Target & $\begin{array}{l}\text { Curriculum } \\
\text { cultivation }\end{array}$ \\
\hline $\begin{array}{l}\text { awareness, understandin } \\
\text { g the theoretical } \\
\text { knowledge of } \\
\text { entrepreneurship }\end{array}$ & $\begin{array}{l}\text { Introduction to entrepreneurship } \\
\text { education } \\
\text { Entrepreneurship } \\
\text { Innovation and entrepreneurship } \\
\text { lecture }\end{array}$ \\
\hline $\begin{array}{l}\text { Entrepreneurial } \\
\text { training }\end{array}$ & Sophomore & $\begin{array}{l}\text { Mastering the basic skills } \\
\text { of entrepreneurship }\end{array}$ & $\begin{array}{l}\text { Entrepreneurship Management } \\
\text { Entrepreneurial team building } \\
\text { Entrepreneurial legal basis } \\
\text { Entrepreneurial Finance } \\
\text { Marketing Management }\end{array}$ \\
\hline $\begin{array}{l}\text { Cultivation of } \\
\text { entrepreneurial } \\
\text { ability }\end{array}$ & Junior students & $\begin{array}{l}\text { Forming professional } \\
\text { Entrepreneurship }\end{array}$ & $\begin{array}{l}\text { Entrepreneurial practice } \\
\text { Simulated Entrepreneurship } \\
\text { Entrepreneurship case study }\end{array}$ \\
\hline $\begin{array}{l}\text { Entrepreneurshi } \\
\text { p practice } \\
\text { training }\end{array}$ & Senior students & $\begin{array}{l}\text { Improving the practical } \\
\text { ability of } \\
\text { entrepreneurship }\end{array}$ & $\begin{array}{l}\text { Campus Entrepreneurship } \\
\text { Program } \\
\text { Campus Entrepreneurship } \\
\text { Program }\end{array}$ \\
\hline
\end{tabular}

Entrepreneurship education, which is the premise and foundation to promote the development of entrepreneurship education, is regarded as same position with the academic education and occupation education by UNESCO. In this context, more and more colleges and universities began to focus on the future development of entrepreneurship education. Students also began to actively participate in business practice, putting forward objective requirement to the entrepreneurship curriculum system in Colleges and universities' structure. How to integrate the professional education and entrepreneurship education of tourism management and make them coordinate and cooperate with each other, so as to promote the cultivation of applied talents of tourism management specialty, still needs human beings to think and explore constantly in modern society.

\section{References}

[1] Q.N. Deng: Journal of Chengdu Technological University, Vol. 15 (2012) No.1, p.47-50.

[2] Y. Liu, G.D. Yan, W. Meng, Y.T. Quan, J.H. Lu, L.R. Teng and Q.F. Meng: China University Teaching, Vol. 30 (2014) No.11, p.35-37.

[3] L.H. Weng: China Higher Education Research, Vol. 30 (2014) No.5, p.85-88.

[4] X.Y. Wang and E.L. Liu: Vocational Technology, Vol. 15 (2016) No.9, p.21-25+30.

[5] J. Gao: Journal of Innovation and Enterprise Education, Vol. 2 (2011) No.4, p.23-25.

[6] Information on http://www.askci.com/news/chanye/2016.01/13/161853tpx1.shtml.

[7] J.P. Stephen: Tourism Management (Florence Production Ltd, Routledge 2015).

[8] N.S. Richard, L. Ruhanen, N. M. Breakey: Current Issues in Tourism, Vol.19 (2016) No.6, p.513-527.

[9] P.P. Chen, S.P. Wu: Technology Consulting Herald, Vol.4 (2007), No.22, p.249-250.

[10] Y. Liu: Liaoing Provincial College of Communications, Vol.11 (2009) No.3, p.70-72. 